Смирнов I.Г., д. геогр. н., проф. Київський національний університет імені Тараса Шевченка, Київ, Україна

\title{
«ОВЕРТУРИЗМ»: ГЛОБАЛЬНИЙ ВИКЛИК ХХІ СТОЛІТТЯ
}

Зовсім недавно, а саме у 2017 р., у фаховій туристичній літературі з'явився такий новий термін, як «overtourism» ( у перекладі 3 англ. - надлишковий туризм) [1]. Цей термін відображає виклики щодо управління зростаючими туристичними потоками у міських (урбо) дестинаціях та вплив урботуризму на міста та їхніх мешканців. Нині половина населення світу живе в урбанізованих ареалах, а за оцінками, до 2050 р. цей показник сягне 70\%. Зростаюча кількість урботуристів збільшує споживання природних та туристичних ресурсів міст, здійснює соціокультурний вплив та зростаючий тиск на міську інфраструктуру. Тому для урботуризму нині важливим завданням $\epsilon$ ефективне управління потоками урботуристів 3 метою забезпечення позитивних наслідків їхнього відвідання міст як для місцевих мешканців, так і для самих туристів.

Ще задовго до того, як виник термін «оvertourism», ЮНВТО визначила поняття туристичної місткості (пропускної спроможності), «як максимальну кількість людей, що можуть відвідати туристичну дестинацію одночасно без здійснення деструктивного впливу на природне, економічне та соціокультурне середовище та погіршення якості туристичних продуктів, що надаються».

Ця мета може бути досягнута через участь громад (місцевих влад) у розвитку туризму, управлінні туристопотоками, зменшенні сезонності туризму, ретельному плануванні туризму в дестинаціях, яке враховує їхню туристичну спеціалізацію та диверсифікацію турпродуктів, а також максимально можливу туристичну місткість.

Вирішити проблеми, що стоять перед урботуризмом, сьогодні $\epsilon$ набагато складнішим питанням, ніж раніше здавалося. Тому існує нагальна потреба створити дорожню карту сталого розвитку урботуризму та розглядати цей розвиток як складник більш широкої програми комплексного розвитку міст. Нині туризм $є$ одним 3 небагатьох секторів світового господарства, що постійно зростає, забезпечуючи при цьому соціоекономічний розвиток, зайнятість, 
розвиток інфраструктури та експортні (валютні) доходи. Тому $\epsilon$ важливим, навіть критичним, забезпечити узгодження розвитку урботуризму з розвитком міст у світовому порядку денному. Про це нагадує «Нова програма ООН з розвитку міст», що вказує на 17 цілей їх сталого розвитку, при цьому особливо слід виділити Ціль 11 «Зробити міста інклюзивними, безпечними, пружними та сталими», яка повинна стати обов'язковою для всіх країн світу [1].

За декілька останніх десятирічь чисельність міського населення, як і територія міст, динамічно зростали та трансформувалися. Згідно даних ООН у 1990 р. 43\% світового населення проживало в урбанізованих ареалах, на 2015 р. цей показник склав 54\% та очікується його зростання до $60 \%$ у 2030 р. Разом 3 прискореною урбанізацією у світі спостерігається зростання урботуризму через те, що міста вважаються дуже популярними дестинаціями для бізнесового та пізнавально-відпочинкового туризму.

Причинами цього явища $\epsilon$ економічний розвиток та збільшення доходів населення, зменшення транспортних тарифів, розвиток туристичної інфраструктури та зростання середнього класу як в економічно розвинутих, так і в країнах, що розвиваються. За останні десятиріччя кількість міжнародних туристів зросла з 20 млн у 1950 р. до більше 1,3 млрд осіб у 2017 р. ЮНВТО прогнозує, що світовий туризм буде динамічно розвиватися і далі - 3 середньорічним темпом 3,3\% за рік до 2030 р., коли чисельність туристів у світі досягне 1,8 млрд осіб.

Нині дохід, що отримується як від внутрішнього, так i міжнародного туризму, є важливим чинником соціо-економічного та культурного розвитку багатьох міст та міських агломерацій. Разом 3 тим, зростання урботуризму призводить до появи різноманітних викликів щодо забезпечення сталого зростання та практик, які б мінімізували від'ємний вплив туризму в містах, зокрема 3 використання природних ресурсів, соціокультурного впливу, зростаючого навантаження на інфраструктуру та управління мобільністю та концентрацією (скупченнями) туристів.

Останніми роками ці виклики також супроводжувались збільшенням пропозиції проживання туристів у містах через нові віртуальні платформи туристичного сервісу. Як результат, число туристів в містах зросло настільки, що з'явились випадки негативного ставлення місцевого населення до туристів, зокрема через явища надмірного їх зосередження, особливо у центральних дільницях міст, 
надмірного галасу та засмічення, а також інших незручностей, пов'язаних з туристами. Справа навіть дійшла до протестів місцевого населення проти туристів у деяких містах та до виникнення термінів «овертуризм» та «туризмофобія» та їхнє використання у ЗМI.

\section{Список бібліографічних посилань}

1. Overtourism? Understanding and Managing Urban Tourism Growth beyond Perceptions. : UNWTO Library, 2018.URL: https: // www. e unwto. org/doi.pdf 